\section{High Quality Low-Density Artificial Aggregate Related to Starting Materials and Heating Conditions* -Development of high quality artificial low density aggregate $\left(1^{\text {st }}\right.$ report $)$ -}

Artificial low density aggregate (LDA) is mainly used in lightweight concrete. The use of highly efficient LDA is a convenient way to realize a high efficient lightweight concrete, because aggregate occupies $70 \%$ of the volume in concrete. However since emphasis have mainly been placed in the production cost of LDA in the past, high quality LDA has yet been produced.

The purpose of this investigation is to improve the properties of LDA so that it has higher strength and lower water absorption, which in turn will expand its application. The LDA properties such as glass content, grain size of raw material, additional quantity of expanding agent, and heating pattern and the relationship between each property are studied. The results are;

(1) As Nambu et al. (1993) reported that when the glass content of starting material is increased, LDA strength is increased while water absorption is decreased.

(2) Finer the grain size of starting material, higher the strength and lower the water absorption of LDA.

(3) Grain size of SiC (Yakushima-Denko Corp.,CF-4000), as expanding agent, of less than $1 \mu \mathrm{m}$ is effective for the expansion of LDA.

(4) LDA made from perlite with around $90 \%$ glass content has double the compressive strength while only having one tenth of the former LDA.

(5) Decrease of expanding agent addition stabilizes the quality of LDA, because temperature influence becomes small.

KEY WORDS : Artificial Low Density Aggregate, Glass Content, Water Absorption, SiC, Grain Size, Perlite

\section{Introduction}

Concrete properties can be effectively controlled by changing the properties of artificial aggregates, not only density but elastic modulus, toughness and strength. This is because of the fact that aggregate occupies about $70 \%$ of the volume in common cement concrete.

Until now, there has been little investigation into how to improve the strength and water absorption of artificial LDA (abbreviations as per Holm and Bremner ${ }^{1)}$ ). Instead attempts to strengthen low density concrete (LDC) to common concrete strength have focused on the matrix strength of concrete. As the water absorption of the former LDA is more than $5 \%$; it has to be first prepared in a water-saturated aggregate to avoid degrading fresh concrete fluidity, and to prevent pipe blockages while pumping. It has been impossible to produce a higher strength concrete by use of the former LDA as the high watercontaining aggregate increases the water/cement ratio. If the strength of LDA is increased and water absorption is decreased, a high strength LDC can be made, with improved fresh

* Received June 18, 2003 : accepted for publication August 4, 2004.

1. Taiheiyo Materials Corp

2. Taiheiyo Cement Corp

3. Tohoku Unibersity

[For Correspondence] E-mail : hideki-wachi@taiheiyo-m.co.jp (Taiheiyo Material Corp · Wachi) concrete workability. Herein we call it "high quality LDA" which has higher strength and lower water absorption when compared to the former LDA.

As the former LDA has valid crystalline minerals, partial melting occurs in the heating process, which creates a low viscous liquid and contains solids, which produces bubbles. The solids break the bubbles and create open voids. Nambu et al. ${ }^{2-3}$, and Yoshikawa and $\mathrm{Nambu}^{4)}$ showed that higher glass content in the starting material increases the spherical pores which in turn increases the strength of LDA. The production cost of the high quality LDA has always hindered its development. As a result, the basic study of this category has been insufficient.

The purpose of this investigation is to improve the properties of LDA so that it has higher strength and lower water absorption, which in turn will expand its applications. This paper investigates the properties of LDA produced from volcanic rock (perlite) with high glass content, from Okusiri Island in Hokkaido and Niijima Island in Tokyo, as the dominant material. LDA properties such as: density, strength, and water absorption were investigated by changing the glass content and the grain size of the starting materials and by adding additional foaming agent and altering the heating conditions. 


\section{Experiments}

(1) Measurements of glass content by XRD and polarizing microscopy

To measure the glass content, we followed a method suggested by Fisher et al. ${ }^{5-6)}$ and Imai et al. ${ }^{7)}$ who measured the glass content of coal fly ash by XRD. The polarized microscopy (Model OPTIPHOT2-PL, Nikon Corp., Jpn) was used to compensate for the glass-content-results obtained from the XRD (Model 200BV Rota Flex, Rigaku Corp., Jpn).

The igneous rock samples used in this investigation contained the crystal minerals: cristobalite, quartz, feldspar (mainly andesine and a few potash feldspar) and biotite. In this experiment, cristobalite, quartz and andesine were added to glass at various ratios, and 5\% fluorite was added as an internal reference for XRD measurements. We neglected the contents of biotite and potash feldspar in this experiment, as they are generally less than $1 \%$.

Four specimens that had different glass content, determined by the XRD method, had been selected for microscopy reference. Careful crushing and sieving were repeated more than twenty times to obtain sample powder with a size distribution of 45 to $75 \mu \mathrm{m}$. Classified particles were fixed on a slide glass with resin. More than 1,000 particles were counted and specified under polarized microscopy.

(2) Water absorption of LDA related to glass content

Water absorption of LDA, made from the perlite mentioned above and black shale (expanding shale) from Awajishima Island in Hyogo prefecture, was measured. The median size of the materials was about $12 \mu \mathrm{m} .0 .3 \% \mathrm{SiC}$ (Type CF-4000, Yakushima-Denko Corp., Jpn.) and 3\% bentonite (Type Hodaka, Hojun Corp., Jpn) were added as a foaming agent and as a cake forming component for the composite, respectively. Glass content was calculated by the XRD method discussed later in the section. The densities of the measured samples were regulated within $1.15-1.25 \mathrm{~g} / \mathrm{cm}^{3}$. Approximately 3-4 grams of mixed powder was pelletized by hand, except for the case employed in section 6 .

Heating rates in this study were around $40^{\circ} \mathrm{C} / \mathrm{min}$, which are similar to those of the common rotary kiln. Details of SiC being used as an expanding agent will be discussed in a later paper.

(3) Effect of starting material grain size on aggregate properties

Perlite from Niijima Island, with sizes ranging from 5 to $30 \mu \mathrm{m}$, was used. $\mathrm{SiC}(0.3 \%)$ and bentonite $(3 \%)$ was added to the Perlite powder. The density of the fired pellet was regulated to be within $0.625 \pm 0.025 \mathrm{~g} / \mathrm{cm}^{3}$. The water absorption and crushing load were measured for the specimens with diameters of $13.0 \pm 0.5 \mathrm{~mm}$.

(4) Effect of foaming agent grain size on density

The details of the foaming mechanisms of LDA will be discussed in the later report. $\mathrm{SiC}$ reacts with the oxygen of the matrix glass, which results in low viscosity upon firing. This is due to the generation of mainly the $\mathrm{CO}$ and $\mathrm{CO}_{2}$ gas phases. The reaction rate of $\mathrm{SiC}$ depends on grain size when the firing conditions are equal. The reaction rate was tested as a function of grain size.
Table 1 Particle size distribution of commercial $\mathrm{SiC}$ used in this test (\%)

\begin{tabular}{ccccc}
\hline Sample No. & $\begin{array}{c}\text { Particle size } \\
\text { (median: } \mu \mathrm{m})\end{array}$ & $-1 \mu \mathrm{m}$ & $-2 \mu \mathrm{m}$ & $-3 \mu \mathrm{m}$ \\
\hline 1 & 3.76 & 21.4 & 28.9 & 52.7 \\
2 & 2.98 & 23.2 & 37.3 & 62.4 \\
3 & 3.50 & 17.0 & 31.7 & 55.2 \\
4 & 3.39 & 25.0 & 32.6 & 57.2 \\
5 & 3.14 & 19.4 & 33.3 & 60.2 \\
\hline
\end{tabular}

Table 2 Experimental factors and conditions.

\begin{tabular}{lc}
\hline \multicolumn{1}{c}{ Parameter } & Condition \\
\hline Addition of SiC (\%) & $0.1,0.2,0.5$ \\
Holding time at maximum temperature $(\mathrm{min})$ & $1,3,5$ \\
Maximum temperature $\left({ }^{\circ} \mathrm{C}\right)$ & $1,100-1,275$ \\
\hline
\end{tabular}

Table 3 Blending and firing conditions tested in a rotary furnace.

\begin{tabular}{lcccc}
\hline $\begin{array}{l}\text { Particle size of } \\
\mathrm{SiC}(\text { median})\end{array}$ & Bentonite & $\begin{array}{c}\text { Maximum } \\
\text { temperature }\end{array}$ & $\begin{array}{c}\text { Firing time in } \\
\text { furnace }\end{array}$ \\
\hline$(\mu \mathrm{m})$ & $(\%)$ & $(\%)$ & $\left({ }^{\circ} \mathrm{C}\right)$ & $(\mathrm{min})$ \\
\hline 13.1 & 0.15 & 3.0 & 1,180 & $25-40$ \\
\hline
\end{tabular}

Commercial SiC, with a mean size of 3 to $4 \mu \mathrm{m}$, was used. Characteristics of the grain sizes are listed in Table 1. The mixing ratio of the starting materials is perlite from Niijima Island $96.7 \%$, bentonite $3 \%$, and $\mathrm{SiC} 0.3 \%$. All specimens were fired at $1250^{\circ} \mathrm{C}$.

(5) Influence of heating conditions and addition quantities of $\mathrm{SiC}$

To find appropriate conditions that produce stable quality LDA, different addition quantities of $\mathrm{SiC}$, holding time and temperature were tested. Table 2 represents the changes to the following conditions: $\mathrm{SiC}$ addition, holding time and temperature. The dominant material was perlite from Okushiri Island with a median size of $12 \mu \mathrm{m}$.

(6) Firing test by electric rotary furnace (small sized rotary kiln)

To reduce density deviation, $0.15 \% \mathrm{SiC}$ addition was selected from the results described in the discussion. Table 3 represents the material blending and firing conditions. These materials were mixed with water and then caked by filter press. The cake was sintered at $1000^{\circ} \mathrm{C}$. The sintered cake was crushed and sieved classified for particles of $0.4-1.3 \mathrm{~mm}$ in diameter. The classified fragments were then fired at approximately $1180^{\circ} \mathrm{C}$ in an electric rotary furnace (Model KA82, Koakagaku Co., Jpn). The dimensions of the rotary pipe of the kiln were $110 \mathrm{~mm}$ in inner diameter and $1200 \mathrm{~mm}$ in length (length of heating zone: $900 \mathrm{~mm}$, and maximum zone: $200 \mathrm{~mm}$ ). Alumina powder $\left(d_{50}=20 \mu \mathrm{m}, 2 \%\right.$ of the pellet weight $)$ was fed into the pipe to prevent pellet adherence to the pipe shell.

Fired aggregate was cut and polished to $6 \times 6 \times 15 \mathrm{~mm}$ in size to measure the compressive strength and elastic modulus. To measure the strain of the sample, strain gauges ( $5 \mathrm{~mm}$ length, Type: FLA-5-11-3LT, Tokyo Sokki Kenkyujo Co. Jpn.) were cemented on the specimens' surface. Densities were calculated from the volume and weight of the cut samples. As a reference the strength and elastic modulus of the former LDA, made from 


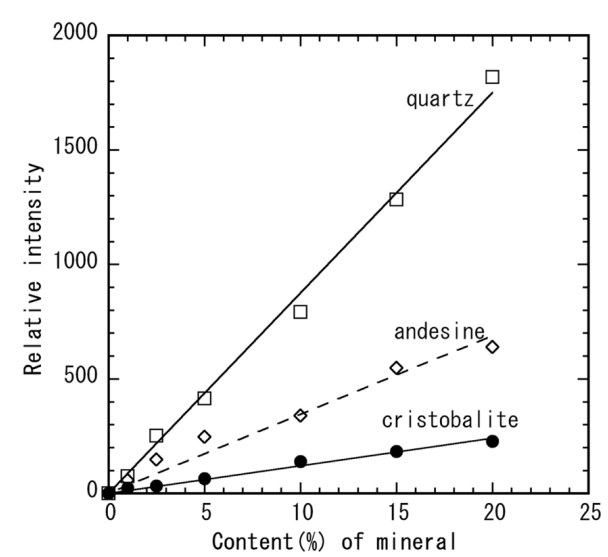

Fig. 1 Relation between mineral content (\%) and relative intensity of XRD peak, normalized to the fluorite intensity of 100 .

Table 4 Results from the counted particles determined by polarized microscopy.

\begin{tabular}{cccc}
\hline $\begin{array}{c}\text { Glass content } \\
\text { By XRD }(\%)\end{array}$ & $\begin{array}{c}\text { Total particles } \\
\text { counted }\end{array}$ & $\begin{array}{c}\text { Number of } \\
\text { crystals }\end{array}$ & $\begin{array}{c}\text { Glass content } \\
(\%)\end{array}$ \\
\hline 97.8 & 1,055 & 84 & 92.0 \\
97.1 & 1,023 & 94 & 90.8 \\
85.8 & 1.068 & 159 & 85.1 \\
80.8 & 1.018 & 163 & 84.0 \\
\hline
\end{tabular}

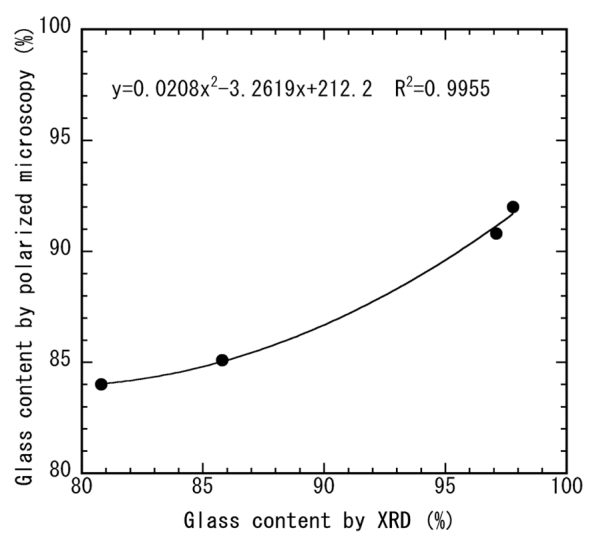

Fig. 2 Relation of glass contents determined by XRD and microscopy method.

expanding shale, were measured. The effect of size was tested by measuring the compressive strength and elastic modulus for a cement paste cylinder of $100 \varphi \times 200 \mathrm{~mm}$ and test pieces of 6 $\times 6 \times 15 \mathrm{~mm}$, which were cut from the cylinder. The water/ cement ratio for the cement pastes was $40 \%$ and the curing time was four days.

\section{Experimental Results}

(1) Quantification of the glass content by XRD measurement

The area or the half width of the XRD-profile is commonly used for quantitative/semi quantitative analyses. For easy/rapid evaluation of glass content in the factory and the quarry, we used the intensity of the main diffraction peak for minerals.

Fig. 1 show a relation between the mineral content and the peak ratio when the peak count of fluorite, the internal standard, is normalized to 100 . Individual relative content $(\%)$ is given as the following empirical equations:

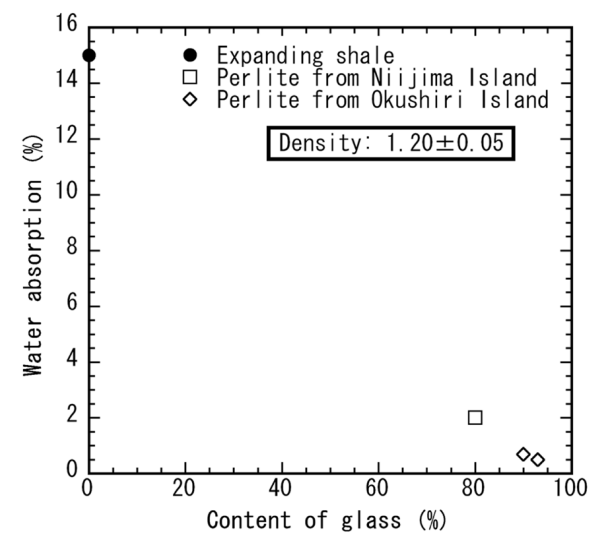

Fig. 3 Relation between glass content of raw materials and (24h) water absorption of LDA.

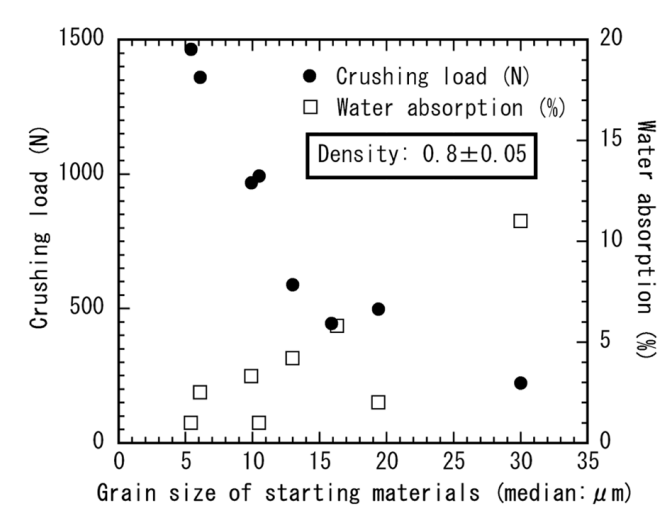

Fig. 4 Effect of grain size on crushing load and water absorption of LDA (LDA size: $12.5-13.5 \mathrm{~mm}$ ).

content of quartz $=$ relative intensity of quartz/87.59 content of andesine $=$ relative intensity of andesine $/ 34.58$ content of cristobalite $=$ relative intensity of cristobalite $/ 12.05$

The maximum glass content was then calculated by subtracting the total crystalline materials from one hundred percent because content of the previously mentioned minerals was negligible.

glass content $(\%)=100-($ cristobalite + quartz+andesine $)$

The microscopy results are listed in Table 4. Though the density of each mineral is different, (quartz: 2.65 , cristobalite: 2.27 , andesine: $2.60-2.75$, glass: $\approx 2.6$, density was not calculated for the following reasons: the total crystal content of igneous rocks was less than $20 \%$, the density of the glass was not clear and the content of cristobalite was less than $5 \%$, therefore any error is negligible.

Fig. 2 shows the comparison of glass content obtained by XRD and microscopy. By assuming that microscopic measurements are reliable, glass content is correlated with XRD-content by the following equation:

glass content $(\%)=0.021(\mathrm{XRD})^{2}-3.27(\mathrm{XRD})+212.2$

(2) Water absorption for different glass content

Fig. 3 shows the results of the relation between glass content and water absorption. It is clear that the increase in glass content decreases the water absorption.

(3) Effect of dominant material grain size on LDA properties As shown in Fig. 4, when the grain size was reduced, the 


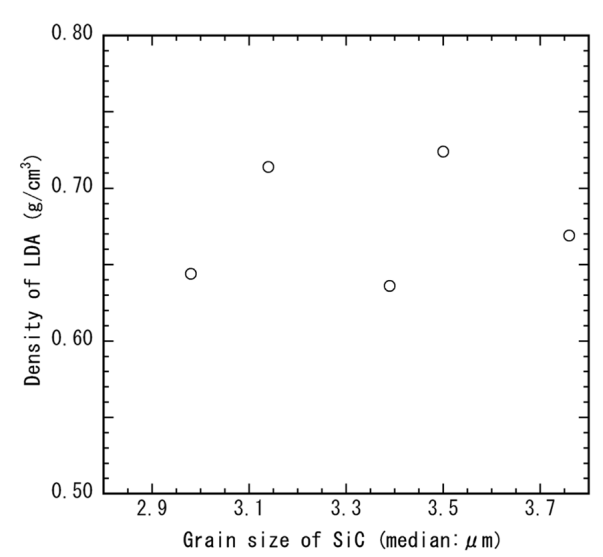

Fig. 5 Relation of median size of SiC to density of LDA.

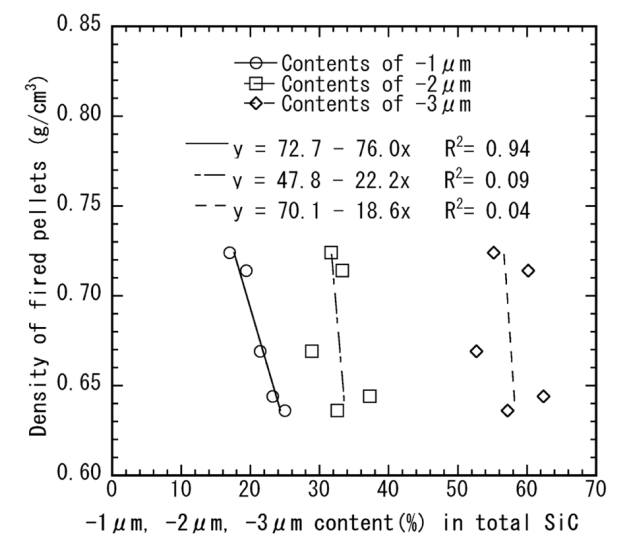

Fig. 6 Relation of -1 to $-3 \mu \mathrm{m} \mathrm{SiC} \mathrm{content} \mathrm{to} \mathrm{density} \mathrm{of} \mathrm{LDA.}$

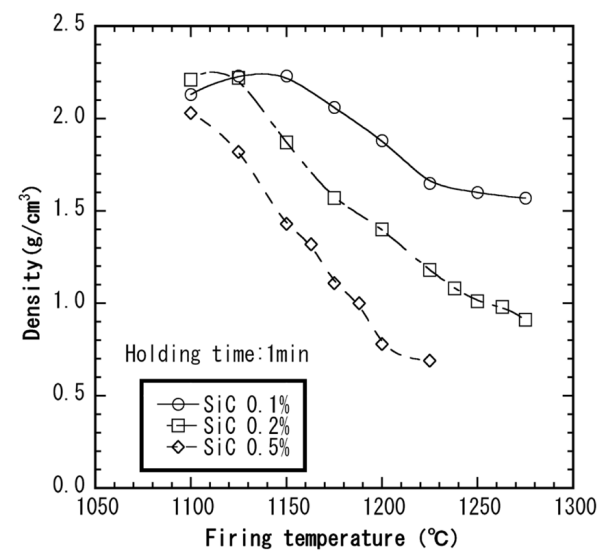

Fig. 7 Density of LDA as a function of firing temperature for holding time (holding time: 1 minutes).

crushing load increased while water absorption decreased.

(4) Effect of SiC grain size

As shown in Fig. 5, there is no relation between mean grain size of $\mathrm{SiC}$ and density of LDA. SiC content of less than $1 \mu \mathrm{m}$ was the most reactive (Fig. 6).

(5) Heating conditions and the addition quantity of $\mathrm{SiC}$

Results are shown in Fig. 7, Fig. 8, Fig. 9. The gradient of density versus temperature decreased as $\mathrm{SiC}$ addition decreased.

(6) Rotary furnace results

A summary of the physical properties for the fired samples

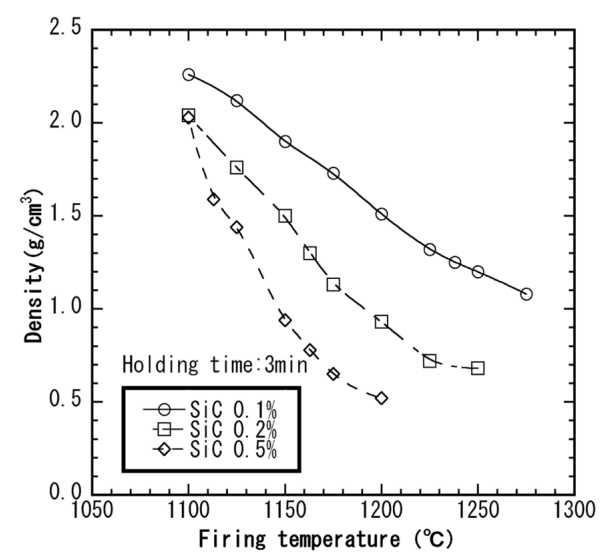

Fig. 8 Density of LDA as a function of firing temperature for holding time (holding time: 3 minutes).

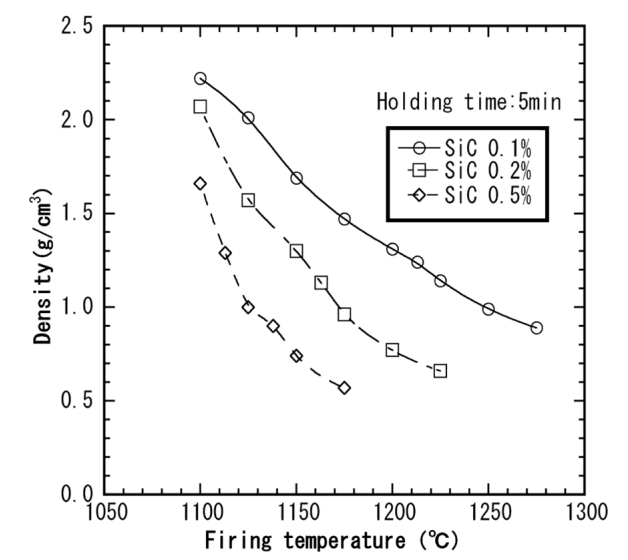

Fig. 9 Density of LDA as a function of firing temperature for a holding time (holding time: 5 minutes).

Table 5 Summary of physical properties of aggregate.

\begin{tabular}{cccc}
\hline $\begin{array}{c}\text { Range of } \\
\text { density }\end{array}$ & $\begin{array}{c}\text { Water } \\
\text { Absorption(\%) }\end{array}$ & $\begin{array}{c}\text { Compressive } \\
\text { strength }\left(\mathrm{N} / \mathrm{mm}^{2}\right)\end{array}$ & $\begin{array}{c}\text { Elastic modulus } \\
\left(\mathrm{N} / \mathrm{mm}^{2}\right)\end{array}$ \\
\hline $0.55-1.20$ & $1.20-0.27$ & $30-70$ & $12,000-21,000$ \\
\hline
\end{tabular}

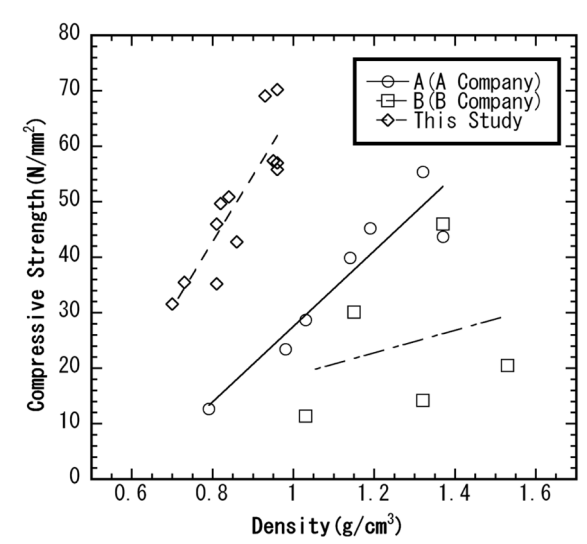

Fig. 10 Relation between density and compressive strength of LDA.

is listed in Table 5. The density of the cut samples $(6 \times 6 \times$ $15 \mathrm{~mm}$ in size) was smaller (by $\sim 0.1 \mathrm{~g} / \mathrm{cm}^{3}$ ) than that of the freshly fired aggregate. This was because the test piece had had its crust removed during cutting and polishing. Fig. 10 and Fig.11 show results from the compressive strength and elastic modulus tests. The LDA strength in this study was approximately twice that of the former LDA, while water 


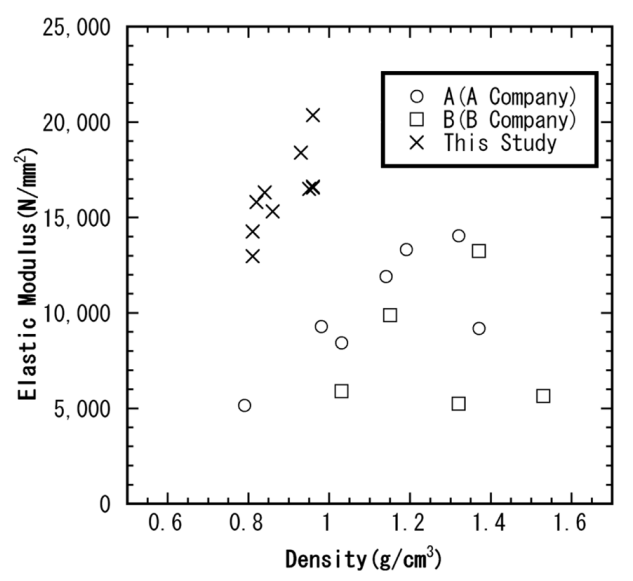

Fig. 11 Relation between density and elastic modulus of LDA.

Table 6 Temperature range that produced desired densities.

\begin{tabular}{ccccc}
\hline \multirow{2}{*}{$\begin{array}{c}\text { Density Range } \\
\left(\mathrm{g} / \mathrm{cm}^{3}\right)\end{array}$} & $\begin{array}{c}\text { Holding Time } \\
(\mathrm{min})\end{array}$ & \multicolumn{3}{c}{ SiC addition(\%) } \\
\cline { 3 - 5 } $0.85 \pm 0.10$ & 1 & - & - & 18 \\
& 3 & - & 24 & 17 \\
& 5 & - & 28 & 18 \\
\hline \multirow{2}{*}{$1.20 \pm 0.10$} & 1 & 42 & 24 & 12 \\
& 3 & 29 & 16 & 10 \\
& 5 & 25 & 15 & 8 \\
\hline
\end{tabular}

absorption was approximately one tenth. The compressive strength and elastic modulus of $100 \varphi \times 200 \mathrm{~mm}$ and $6 \times 6 \times$ $15 \mathrm{~mm}$ test pieces were $52.8 \mathrm{~N} / \mathrm{cm}^{2}(\sigma=2.8)$ and $52.6 \mathrm{~N} / \mathrm{cm}^{2}(\sigma=$ $4.0), 14447.3 \mathrm{~N} / \mathrm{cm}^{2}(\sigma=932.5)$ and $14966.4 \mathrm{~N} / \mathrm{cm}^{2}(\sigma=2315.3)$, respectively $(\mathrm{n}=3)$.

\section{Discussion}

The purpose of this investigation was to improve the properties of LDA. The results (Fig.3 and 4) show that altering the glass content and grain size of the dominant materials can improve LDA properties. It is concluded that materials of fine grain and high-glass content increase the volume of the spherical and closed pores of a fired specimen, which results in a higher quality LDA. Judging from Fig.4, less than $12 \mu \mathrm{m}$ is effective to strengthen and improve water absorption. The size will be determined by grinding cost in actual production.

The XRD method enables rapid determination of glass content to facilitate work in the factory and quarry.

Fig. 6 shows that $\mathrm{SiC}$ with size of less than $1 \mu \mathrm{m}$ react mainly with oxygen of a silicate matrix to generate foaming gas. Therefore, the measurement of grain size is indispensable in industrial usage to achieve a specific density.

From the results shown in Fig. 7-9, the temperature ranges to produce desired densities were calculated (Table 6). The figures show that a decrease in $\mathrm{SiC}$ addition decreases the deviation of density, yet the firing temperature and holding time in the kiln deviate. The upper temperature limit is just before the aggregate decreases in viscosity, and starts to deform and adhere with each other and the kiln shell.

As mentioned in the above results, a ratio of $\mathrm{SiC}$ addition

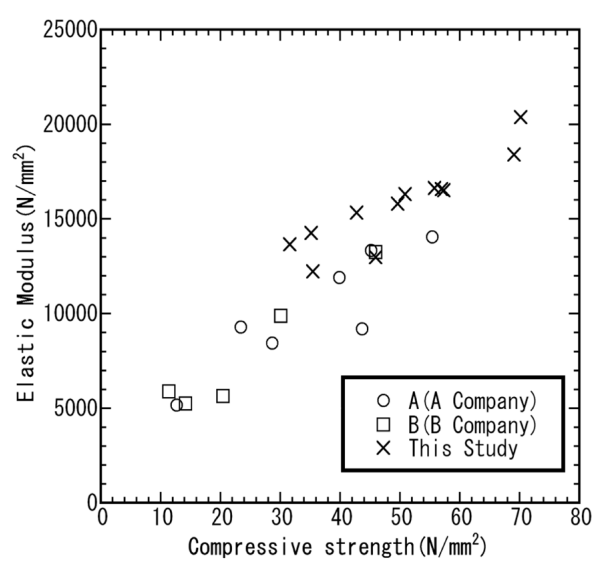

Fig. 12 Relation between compressive strength and elastic modulus of LDA.

was chosen from the rotary furnace test. The results demonstrate that the strength of LDA in this study, was approximately twice that of the former LDA, while the water absorption was approximately one tenth. The size effects of strength and elastic modulus were small. The data from the small size test piece can be applied to the common size sample as they had equal size ratios. For example, the strength of a specimen, with a density of $1.0 \mathrm{~g} / \mathrm{cm}^{3}$ reaches to $60-70 \mathrm{~N} / \mathrm{mm}^{2}$ which is suitable for use as a high strength LDC $\left(>40 \mathrm{~N} / \mathrm{mm}^{2}\right)$ without any further treatment. Since water absorption was approximately $1 \%$, which is similar to that of natural aggregate, slump loss of fresh concrete is decreased and pumping is possible, even if the aggregate is used in dry state. We expect to produce a lower water cement/concrete from the use of this LDA. This LDA will have expanded application possibilities.

Fig.12 shows the relationship between compressive strength and the elastic modulus, which is data from Fig. 10 and 11. In the case of the LDA tested, the elastic modulus is related to compressive strength.

The aggregate produced in the rotary furnace was used for concrete tests, which will be published in a later paper.

In conclusion to this fundamental investigation, the key to producing high quality aggregate is to know how to develop spherical pores in the LDA.

\section{Conclusion}

A basic study to produce high quality LDA was carried out. The conclusion is as follows:

(1) A rapid analysis of the glass content in the raw materials by XRD was established and is applicable for use in factories and qaurrys.

(2) The higher the glass contents of the starting materials, the lower the water absorption.

(3) A higher quality LDA is produced from finer materials.

(4) Particle size of SiC that is less than $1 \mu \mathrm{m}$, is efficient as a foaming agent.

(5) Lesser $\mathrm{SiC}$ addition results in a LDA with less deviation in density.

(6) High quality LDA is effective for producing high strength LDC, with more than $40 \mathrm{~N} / \mathrm{mm}^{3}$ in compression 
strength (LDA density: $1.0 \mathrm{~g} / \mathrm{cm}^{3}$ ).

(7) Fresh concrete produced here will have low slump loss, and good "pump-ability", even if the LDA is used under a dry state. This is because high quality LDA has similar low water absorption characteristics as that of natural aggregate.

(8) This type of LDA will have expanded applications.

\section{References}

1) T. A. Holm, and T. W. Bremner: "State-of-the-Art Report on High-Strength, High Durability Structural Low-Density Concrete for Applications in Severe Marine Environments." US Army Corps of Engineers, Eng. R \& D Center, (2000), pp.1-2.
2) M. Nambu, T. Tanosaki, K. Kusaka and K. Nitta: "Morphological study of the foam of artificial lightweight aggregate related to its strength," Proc. of Fall Meeting of the Ceram. Soc. Jpn., (1993), p.274 (Japanese).

3) M. Nambu, N. Hayakawa and Y. Saito: "Study on lightweight aggregate from pumice tuff," Bull. Res. Inst. Min. Dress. and Metal. Tohoku Univ., 47(1991), pp.105-112 (Japanese).

4) T. Yoshikawa and M. Nambu: "Evaluation of Shape in expanded inorganic materials by image processing," J. Res. the CHICHIBU ONODA Cement Corp, 47(1996), pp.126135 (Japanese).

5) G. L. Fisher, B. A. Prentics, D. Silberman, J. M. Ondov, R. C. Ragaini, A. H. Biermann, A. R. McFarland, and J. B. Pawley: "Size-dependence of the physical and chemical properties of coal fly ash", Am. Chem. Soc. Meeting, Div. Fuel Chem. Symp., Properties of Coal Fly Ash, Montreal, Canada, May, 22(1977), pp.149-155.

6) G. L. Fisher, B. A. Prentics, D. Silberman, J. M. Ondov, A. H. Biermann, R.C. Ragaini, and A. R. Mcfarland: "Physical and morphological studies of size-classified coal fly ash", Environ. Sci. and Tech., 12(1978), pp.447-451.

7) T., Imai, T. Tanosaki, M. Nambu, and K. Nakatsuka: "High temperature behavior of Fly Ash," J. Min. Mat. Proc. Inst. Jpn, 144(1998), pp.952-958(Japanese).

\section{高性能人工軽量骨材の原料および焼成条件の諸特性}

\section{- 高性能人工軽量骨材の開発 ( 第 1 報 )-}

\section{和 知 秀 樹 $^{1}$ 井 澤 泰 雄 $^{2}$ 南 部 正 光 $^{3}$ 中 塚 勝 人 $^{4}$}

人工軽量骨材 (LDA) は主に軽量コンクリート用材料として使 用されている。骨材はコンクリート中で $70 \%$ の体積を占めること から, 高性能 LDA の実現は高性能軽量コンクリートを実現する近 道である。従来，LDAの製造は低コスト化に重点が置かれ，高性 能 LDA は製造されていなかった。

本研究の目的は, LDA の用途の拡大をめざし, 従来品より高強 度で低吸水率の LDA を開発することである。第 1 報では, 原料ガ ラス含有率, 原料粒度, 発泡剂添加量, ヒートパターンと LDAの 物性との関係を研究した。その結果

(1) 既に南部・他 (1993) が報告したように, 本研究でも, 原料 中のガラス含有率が増加すると強度は増加し吸水率は減少す る。

(2) 原料粒度は細粒化するほど LDA の強度は増加し, 吸水率は 低下寸る。
(3) 発泡材としての $\mathrm{SiC}$ は $1 \mu \mathrm{m}$ 以下の粒径が LDA の発泡に大 きく寄与する。

(4) ガラス含有率が約 $90 \%$ 程度の真珠岩を使用した LDA の圧 縮強度は従来の LDA の 2 倍程度であり, 吸水率は 10 分の 1 程度である。

(5) 発泡剂の添加量を減少させると物性の温度依存性を少なく するので, LDAの品質の安定化が図れる。

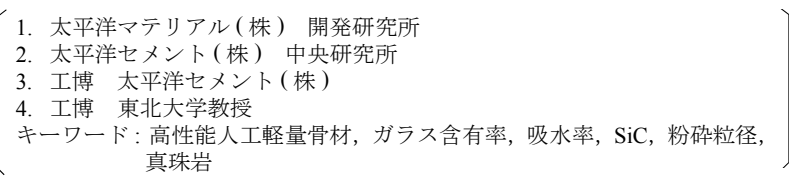

